\title{
Słowa ponad granicami. Literackie świadectwa kontaktów kulturowych
}

Jacek Wójcicki 


\section{Słowa ponad granicami. Literackie świadectwa kontaktów kulturowych}

\footnotetext{
A

rtykuły zgromadzone w niniejszym tomie „Napisu” dokumentują konferencję, która pod takim tytulem od 12 do 14 października $20(15$ roku w złotym jesiennym Cieszynie zgromadziła szereg referentów z różnych ośrodków badawczych kraju. Nadgraniczne miastow krainie hojnie obdarowanej przez przyrodę i nieoszczędzancj przez historię, petne malowniczych zabytków trudnej wspólnej egzystencji kilku narodów, centrum żywej międzynarodowej wymiany kulturalnej i naukowej - Cieszyn jak mało które miejsce unaocznia jednoczesną realność i umowność granic; twardą rzeczywistość i dzicjową nieuchronność podzialów etnicznych, religịnych czy polityczno-administracyjnych, a zarazem ich względność, plynność i przenikalność w aspekcie intelektualno-duchowym. Dzieje Sląska Cieszyńskiego uświadamiają, jak liczne i nie’uniknione bywają przyczyny, zmuszające ludzi bliskich kultura, językicm i obyczajami do wrogiego stawania przeciw sobie, i zarazem jak niewicle nieraz trzeba, by ten dystans skracać. Ale przybywając na tę zicmię ludzi rzetelnych i trzeźwych, nie ma też sensu się łudzić: znacznie częściej przychodzi pokonywać bariery z mozolem niż ze śpiewem.

Uczestnicy konferencji, stawiający sobie za cel namysł nad różnorodnymi literackimi śladami międzykulturowych spotkań i sporów, trafili zatem do miejsca, gdzie tchnie ożywczy dla podobnych rozważań genius loci. Przekonali się zarazem, że to chyba tenze duch miejsca wyzwala w nawyklych do tolerancji Cieszynianach gościnność i otwartość, dzięki której obrady i dyskusja miały tyleż charakter intensywnej wymiany poglądów, co serdecznego spotkania znajomych.

Siedzibą tej kilkudniowej rozmowy byla Książnica Cieszyniska, której dyrektor mgr Krzysztof Szelong wraz z życzliwym personelem zapewnił uczestnikom możliwość obrad w imponującym gmachu biblioteki, już samą architekturą symbolizującym wspomnianą ambiwalencję pojęcia granicy oraz ciąglość tradycji - za nowoczesną szklaną ścianą wcho-
} 
dzący czytelnicy od razu dostrzec moga zabytkowe regały z bezcennymi zbiorami pioniera cieszyńskiego muzealnictwa i bibliotekarstwa, Leopolda Jana Szersznika (1747-1814), w roku 1802 udostępnionymi przezeń publiczności jako pierwsza tego typu placówka na Śląsku austriackim. W tym samym wnętrzu goście mogli zapoznać się z trwającą od lata ciekawą wystawą Granice w'ytyczane stourami. Konflikty na Śląku Cieszyniskim u'suietle literatury politycznej (1848-1947), świetnie korespondującą z profilem konferencji.

Uroczystego otwarcia obrad dokonali przedstawiciele wladz regionalnych: Starosta Powiatu Cieszyńskiego Witold Dzierżawski, Burmistrz Cieszyna dr inz. Bogdan Ficek i jego zastępca, mgr inż. Jan Matuszek. Po inauguracji przystapiono do obrad, zaplanowanych kolejno w sześciu blokach tematycznych:

\section{Między' Ślaskie'm a Kurlandia}

1. prof. dr hab. Anna Tyrpa (Akademia Świętokrzyska, Kielce; Instytut Języka Polskiego PAN) - Pieśni ludon'e jako dokument kontaktón' Ślqzakóu' z cudzoziemcami i obcymi krajami;

2. dr Pawel Kaczyński (Uniwersytet Wroctawski) - Czeskie przygody polskich oświeconych - podróze Polakóu' do Czech "X' XIII u'ieku;

3. dr Aleksandra Norkowska (Uniwersytet Kazimierza Wielkiego, Bydgoszcz) - „Dic Deutsche Muse uagst Dir, Herr, ein Lied zu singen". Kurlandia i poetycki konterfekt Stanistau'a Augusta Poniatouskiego;

4. dr Łucja Dawid (Uniwersytet Śąski w Katowicach) - Jedna religia, durie poetyki. Jana Kubisza przygoda translatorska.

II. Widokizza przedmuraa

5. dr Piotr Pirecki (Uniwersytet Eódzki) - Rylatt w' drodze;

6. mgr Weronika Girys-Czagowiec (Instytut Slawistyki PAN, Warszawa) - Obraz siedemnastou'ieznej Polski i jej mieszkańcóu' u' oczach cudzoziemcóu;

7. mgr Małgorzata Trębska (Uniwersytet Warszawski) - „Którzy głou'y' su'ych ojcóu' jedli” - kultury' obee u' staropolskich oracjach u'eselnyell;

8. mgr Marcin Bauer (Uniwersytet Łódzki) - Nad „Prze'u’agami elearóu polskich” Wojciccha

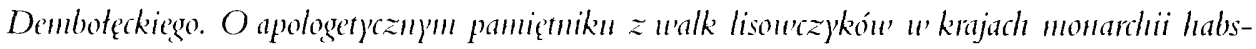
burskicj podczas pienu'zzch lat wojny trzydziestoletniej;

9. dr Michał Kuran (Uniwersytet Eódzki) - Turcy i Tatarzy' u' oczach Jakuba Kimikou'skiego u'edtug „Dziejón tureckich” Marcina Paszkouskiego;

10. dr Elwira Buszewiczowa (Uniwersytet Jagielloński, Kraków), dr hab. Piotr Urbański (Uniwersytet Szczeciński) - „Cammen panegy'ricum” Willelma Smitha (1679) — zu'ycięstu'o Jana Sobicskiego nad Turkami z perspekty'u'y' angiclskicj.

III. Pogranicze polsko-francuskie

11. dr Tomasz Slęczka (Uniwersytet Wrocławski) — Śląsk i jego mieszkanicy w' oczach polskich zotnierzy Napoleona I; 
12. dr Jacek Wójcicki (Instytut Badań Literackich PAN, Warszawa) - Ok'upant - rozjemca. O poemacic Omufrego Kopezpriskiego „De I arsal'iensi conlictu...”;

13. prof. dr hab. Roman Jaskula (Akademia Pedagogiczna im. Komisji Edukacji Narodowej, Kraków) - Polak u' Paryzu. Zuinzki Karola Forstera z kultura francuska u.XIX uicku.

IV. Europa Stourian - bez granic?

14. prof. dr hab. Elżbieta Malinowska (Uniwersytet Śląski, Katowice) - Stanistan'a Tarnow'skiego u'rażenia z pobytu u' Moskurie;

15. dr Grażyna Legutko (Akademia Świętokrzyska, Kieke) - Mistrz - przyjaciol - inspirator. Jarostau' Lrchlicki u' oczad Zenona Przesmyckiego (Miriama) w'surietle korespondencji zlat 1883-1901;

16. doc. dr hab. Olga Ciwkacz (Uniwersytet Podkarpacki im. W. Stefanyka, Iwanofrankowsk - Ukraina) - Obraz Huculszczyzny' u' listach Stanistau'a Vincenza;

17. dr Katarzyna Krasoń (Uniwersytet Szczeciński) - Wzurerciadle obcej literatur)' (recepcja Zbignieu'a Herberta "Niemczech);

18. mgr Marcin Telicki (Uniwersytet im. Adama Mickiewicza, Poznań) - Zu'iqzki tu'órzze Julii Hartu'ig z kulturq francuske.

\section{V. „Kresy”- su'ojskic i egzotyczme}

19. prof. dr hab. Maria Wichowa (Uniwersytet Eódzki) - Sarmacki oglad súmiata u' "Nou'ych Atenach" ks. Benedykta Chmielow'skiego;

20. mgr Aleksandra Kijak (Uniwersytet Jagielloński, Kraków) - Śmiadectu'a kontaktóu' kulturou'ych u' listad, pamiętnikad i uspomnicniad Wactau'a Sicroszen'skiego;

21. dr Paweł Zajas (Uniwersytet inn. Adama Mickiewicza, Poznań) - Postkolonialne echa z Potudniourej. Afryki. Egzotyczny kostium patriotyzmu u' ctnografii Antoniego Rehmana (1840-1917).

\section{Znad ksiqzick}

22. dr Magdalena Rzadkowolska (Uniwersytet Eódzki) - Kobicta żydou'ska, kobieta czytająa;

23. dr Daria Mazur (Uniwersytet Kazimierza Wielkiego, Bydgoszcz) - Pośrednictuo lekturou'e. Literackie inspiracje "u' escistyce Józefa Czapskiego;

24. dr Ryszard Nowicki (Uniwersytet Kazimierza Wielkiego, Bydgoszcz) - Zabezpieczanie ksiegozbioróu' po II u'ojnic sumiatou'ej u' Polsce.

Wszystkim przedstawionym referatom towarzyszyła ożywiona dyskusja.

Gospodarze zadbali też o wypoczynek, podtrzymanie sił witalnych uczestników i o ich godziwą rozrywkę. Tę część zadań jako współorganizator wziął na siebie Wydział Etnologii i Nauk o Edukacji Uniwersytetu Śląskiego w Katowicach - Filii w Cieszynie, a bezblędna ich realizacja byla zasłıg̨ imiennie dr Eucji Dawid. Dzięki niej biorący udział w konferencji mieli okazję podczas uroczystego spotkania w rotundowej Kawianni Muzealnej wysłuchać koncertu muzyki dawnej w wykonaniu zespołu kameralnego pod kierunkiem mgr Grażyny I Ieller. 
Cieszyńskim współorganizatorom referenci i goście konferencji zawdzięczali też możliwość zwiedzenia Cieszyna z dyrektorem Muzeum Miejskiego, drem Januszem Spyra, pracownikiem naukowym Uniwersytetu Śląskiego. Przemierzając pod jego kierunkiem place, ulice i wzgórza Cieszyna, uczestnicy wycieczki wędrowali zarazem w przestrzeni i czasie, bowiem punkt wyjścia - siedziba Ksiąznicy przy Menniczej 46 na skraju Placu Teatralnego - znajdıje się w najstarszej części dawnego podgrodzia, a mijając secesyjny Teatr im. Adama Mickiewicza i ulicą Menniczą przez Stary Targ przechodząc w stronę Rynku, zwiedzający śledzili zarazem kierunck rozwoju miasta nad Olzą.

Realizację konferencji umożliwili także pozostali współorganizatorzy: Instytut Filologii Polskiej Uniwersytetu Wrocławskiego, Pracownia Literatury Okolicznościowej i Użytkowej Uniwersytetu Warszawskicgo oraz Zespół Badań Obszarów Trzecich Literatury Instytutu Badań Literackich Polskiej Akademii Nauk. Patronatem medialnym konferencję objęły: regionalna rozgłośnia Radia Katowice, „Gazeta Wyborcza” i tygodnik „Polityka”.

Życie, jak to zwykle bywa, dokonało korekt w projekcie - część referatów została zaprezentowana istotnie „ponad granicami” czasowymi bloków pierwotnie wyznaczonych (wystąpienia Michala Kurana, Marii Wichowej i Marcina Telickiego), niektórzy referenci, nieobecni w Cieszynie, nadestali swoje wystąpienia później (Weronika Girys-Czagowiec, Grażyna Legutko, Olga Ciwkacz), dwóch autorów obecnych w Książnicy poprzestało na formie mówionej, wreszcie cztery osoby - nie zostały dotąd i nie będa tu wymienione - mimo zgłoszenia tematów nie pojawiły się na konferencji ani nie dostarczyły tekstów do tomu.

Uzupełnieniem tematyki konferencji jest w nim nadesłany „ponad granicami” z Portugalii artykul dr Beaty Cieszyı́skiej (Uniwersytet Kazimierza Wielkiego w Bydgoszczy), zaś w dziale Íaria prezentujemy tekst dra Grzegorza Szelwacha (Warszawa) i komentowaną edycję dwóch dokumentów w opracowaniu mgra Marcina Kuźmy, doktoranta Uniwersytetu Warszawskiego.

Zamieszczone powyżej — jak przystało na pismo poświęcone literaturze bliskiej życiu — zestawienia i statystyka obrazują naszą działalność konferencyjno-redakcyjną w pierwszym roku nowego dziesięciolecia „Napisu”. Teraz juz serdecznie zachęcamy do lektury: oto przed Easkawymi Czytelnikami stają otworem granice wiedzy. 